\title{
CALDERÓN'S USE OF HISTORY IN EL POSTRER DUELO DE ESPAÑA
}

Guy Rossetti

El postrer duelo de España is heavily dependent on old Spanish history. Its central episode - the duel - is taken directly from the chronicles of Charles V. Other minor historical incidents are introduced in the plot without maintaining any apparent historical sequence. In addition, Calderón adds to this historical flavor by establishing as characters in this play some of the leaders of the most powerful and noble families of Spain. Besides Charles V, the list of characters includes such notables as Fradrique Enríquez, the Admiral of Castile; Iñigo Fernández de Velasco, Constable of Castile; Alonso Pimentel, Count of Benavente; and Kasimir, the Marquis of Brandenburg, representing the Hohenzollern family of Germany. Lesser roles are also assigned to the Dukes of Albuquerque, Bejar, and Alba and the representatives of the houses of Nágera and Aguilar. Mentioned, but not appearing on the stage, are Maximilian, Emperor of Germany, and Pope Paul III.

The purpose of this paper is to attempt to show Calderón's craftmanship by comparing the historical incidents with its dramatic rendition. It goes without saying that the idea is not to compare two methods of communication and arrive at a qualitative judgment. The comparison will simply afford us to glimpse at Calderón's artistry while developing a theatrical piece with a universal message out of relatively unimportant historical episodes. A close look at this transformation will hopefully reveal the artistry of a master playwright at work. The fortunate existence of the source of this play of Calderón affords us an excellent opportunity to study the subtle, and not so subtle, variations that transform history to drama.

Besides having characters that represent prominent historical figures, Calderón also specifically mentions some historical incidents and alludes to others. Some of these incidents are told when and how they occurred, some are taken out of their temporal context, and others are obvious distortions of known facts. These changes are neither arbitrary nor accidental. It is imperative that we look at these changes not in terms of their lack of historical accuracy, but in terms of their functions in the exposition of the main theme.

Following Aristotelian poetic principles, ${ }^{1}$ the dramatic theories of the seventeenth century demanded that when necessary dramatic poetry should and must emend history in order to satisfy the requirements of Art. Bances Candamo, a contemporary and a disciple of Calderón, wrote that it was the objective of dramatic poetry to entertain the audience and at the same time instruct it to live happily and honestly. For such an end the comedia is better than history because, according to him, the comedia: 


\begin{abstract}
"es la historia visible de el pueblo, y es para su enseñanza mejor que la historia, porque como la pintura llega después de la naturaleza y la enmienda imitándola, assi la Poesía llega después de la historia, $i$ imitándola la enmienda. . . Imita la comedia a la historia, copiando sólo las acciones airosas de ella, y ocultando las feas; finalmente, la historia nos expone los sucesos de la vida como son, la comedia nos los exorna como devian ser, añadiéndole la verdad de la esperiencia mucha más perfección para la enseñanza. Reduce a la clausula de dos horas los acaecimientos de muchos años, poniéndoles tan naturales que parece que no pudieron suceder de otro modo, y espresándolos tan vivos que se cree que entonces están sucendiendo". ${ }^{2}$
\end{abstract}

It is the objective of the historian to record history as it happened while the dramatic poet records it as it ought to have been. The alterations are consciously made in order to serve the dramatist's moral didatic end. Unlike the historian, the dramatist does not have to follow historical events closely, for he does not set out to reproduce reality, but to present the meaning or lesson of a given historical event. Conscious that a dramatic piece should not be mistaken for reality, the barroque dramatist felt free to alter the historical sequence of events as they happened.His concern was directed at the possible significance of an action rather than on the action itself. This gave him the freedom to adapt history to his own dramatic needs.

More recently Professors A. E. Sloman and A. A. Parker have also written on the application of these principles in the historical plays of the Golden Age. ${ }^{3}$ In an earlier monograph, Parker summarizes it this way:

The theme of a play is some analysis of human nature and conduct that is universal in its application, independent of space and time. Dramatists are poets not historians, and the object of dramatic poetry is the universal, while that of history is the particular. A historical theme, for Spanish dramatists, was exactly the same as a contemporary one - a medium for expressing $a$ universal truth, not for painting a historical picture. ${ }^{4}$

It is important to remember that although the play is based on historical events, the dramatist is not dramatizing history, but rather he is writing dramatic poetry based on historical incidents. The playwright has no special duty to be loyal to the accuracy of historical events as does the historian and the chronicler. The dramatist uses the historical incidents, altering and adjusting them to fit his dramatic purpose which is, as in all good art, the elucidation of a universal truth. The fact that there is not an exact correspondence between the historical and the poetic is inapplicable to the objectives of the dramatist. The lack of correspondence should not offend our historical sensibilities. On the contrary, it should direct our attention to the purpose of the distortions and demonstrate that the manipulation of historical events is really essential to the exposition of the moral principle of the dramatic work. Rather than obey historical truth, Calderón, 
as an artist of the seventeenth century, chose to obey a moral truth, which often turned out to be lesson that one was to extract from the historical incident.

In El postrer duelo de España Calderón dramatizes an actual duel that took place before the court of Charles V in December of 1522 in Valladolid. Historically this duel was the very last one ever fought in Spain with the approval and protection of the Court.

Calderón used as his source the account of this duel presented by Fray Prudencio de Sandoval in a volume titled: Vida y hechos del Emperador Carlos V. ${ }^{5}$ Sandoval relates that two young gentlemen from Aragon, don Pedro de Torrellas and don Jerónimo de Ansa had a quarrel over a ball game. The two friends and cousins challenged each other to a secret duel. While fighting the duel, Torrellas inexplicably dropped his sword. He immediately admitted his defeat and asked Ansa to either kill him - in that way dying in the field of honor - or to allow him to live, but with the promise to keep the offending matter secret between the two of them. Ansa acceded to this friend's wishes and promised not to reveal to anyone what had transpassed between them. However, unknown to the two of them, there had been a witness who quickly divulged the matter throughout the city. Torrellas accused Ansa of betraying his promise as a gentleman. Ansa justly denied having done so. Unable to reach an amicable settlement, the two petitioned the Emperor for permission to fight till death a public duel "conforme a los fueros de Aragón y leyes antiguas de Castilla." The petition was granted and the duel was fought on December 29 in Valladolid before the Emperor and his court. The two fought valiantly. The Emperor, recognizing their valor, ordered that the duel be terminated, declaring that neither had won over the other and that both had retained their honor. He ordered them to be friends again and to employ their energies in the service of the faith and the king. The two protested the ruling so vigorously that the Emperor had them incarcerated, and even after they were released, they refused forever to be friends again. Sandoval concludes: ". . .así acabaron las vidas necia y apasionadamente, que son condiciones de los pundonores humanos".

Calderón remains loyal to this historical account of Sandoval to such an extent that at times he simply puts in verse the words that Sandoval had written in prose. However, he adds some new circumstances to the duel and changes other details thereby turning this relatively insignificant incident into a meaningful message for all men. Among the various emendations and additions that Calderon makes in this dramatic rendition of this duel, a close look at three of them will help us to make our point. The three changes include: supplying a specific reason for the duel, supplying a specific reason as to why Torrellas drops his sword, and supplying an ending that is much more concerned with the dramatist's moral didatic end than it is with maintaining historical accuracy.

Calderón's purpose in using this duel as the dramatic center for his play is not simply to reproduce a vignette on an old custom ot to just simply censure or condemn the duel. There is no doubt as to Calderón's ire towards the duel, and throughout the play he repeatedly condemns it as a barbaric custom. The condemnation of the duel, however, could not have been his main purpose because the duel had already been condemned by the Council of Trent almost a hundred years earlier. There is a more important reason as to why he chose this duel, and that reason resides in the detailed explanation that 
Calderón gives as to why the two friends and cousins challenge each other in the first place.

In the historical duel, the chronicle dismisses lightly the reason for the duel: a simple quarrel at a ball court. And although this is how it happened historically, dramatically this explanation is too frivolous. There just was not in it a theme for a serious play. So Calderón, using history as a base, invents his own motive for the duel. He does so not to simply criticize the duel, but to criticize a much more universal subject: honor.

In Calderón's play, don Pedro Torrellas is secretly pledged to Violante. As a matter of fact the two live together secretly as man and wife. The two lovers live together secretly because they do not have the financial means to properly maintain a household according to their station in society. That is to say, they cannot marry publicly for reason of social honor. Therefore, to protect this financial honor or honor of appearance, the two jeopardize their private honor. To maintain this public honor they get involved in an immoral - al though legal - and dangerous situation where to preserve a public honor they must lose the private one by living in a secret cohabitation. The pursuit of this social honor eventually produces a public dishonor for the two and causes discord among friends and relatives.

Because no one knows that Violante is already promised, she is fair game for anyone. The first man to show interest in her is don Jerónimo de Ansa, Pedro's best friend and cousin. Jerónimo, without tellings his friend the target of hid advances, asks Pedro to help him in his amorous adventure. Don Pedro, on the other hand, ignorant of the fact that his friend's advances are directed at his betrothed agrees to lend him a hand. When he discovers that Violante is the object of Jerónimo's love, he attempts to discourage his friend from continuing his quest by revealing, against the promise he had made to his lady, his relationship with Violante, for he arrives at the erroneous conclusion that his honor is more important than his lady. He puts it this way:

rompa la presa el silencio,
y ponga mi honor en salvo;
que si dijo algún proverbio:
"Antes que todo es mi dama,"
mintió amantemente necio;
que antes que todo es mi honor,
y él ha de ser el primero.

Breaking his promise to Violante and putting honor above his lady are the first consequences of his pursuit of the social honor. Another consequence is that don Jerónimo does not accept don Pedro's explanation and accuses him of being less than sincere with his best friend. Having arrived at this impass, the two decide to settle the matter with a secret duel. From here the play picks up the plot of the historical duel.

This addition to the historical episode is extensive and very important to the play. In it lies the very important message missing in the Chronicle's accounts. That message, simply stated, is that the pursuit of social honor leads to secrecy, jealousy, the duel, and the unnecessary exposure of one's life to death. Calderón, like Sandoval, grants 
don Pedro and don Jerónimo the legal right to the duel, but unlike the historian, the dramatist makes it a point to draw a line between the legal right and the moral one. The latter, of course, corresponds to the universal, while the former to the specific. When the two characters confuse their moral values with their legal rights, they choose, on a symbolic plane, disorder over order. Honor which is the basis for the clandestine cohabitation, also forms the base for the fighting of the duel. It forces Jerónimo to insist on the duel, even after he has learned the truth, and it forces Pedro to gamble his lady and his marriage. Honor conceived in this way draws people apart. It destroyes all human ties, sabotages love, and above all it demands vengeance and death as its price. Human affection and compassion, so dear to Calderón, are shunned aside, while honor and vengeance occupy the foreground. The association of the duel with the contemporary code of honor means that the duel is for Calderón a symbol of the enslaving affects that such a code has on well-meaning men and women.

Another much more subtle, but nevertheless important deviation from the historical accounts of this duel, is the different reasons that the historian and the dramatist give for don Pedro's dropping of the sword during the secret combat. Sandoval gives no importance, nor should he have, as to why don Pedro looses his grip on the sword. To have recorded that it happened is enough for his purpose. Therefore, he merely says: "O por desgracia o por consancio y flaqueza del brazo, se le cayo la espada al Torrellas de la mano." The historian is interested in the "fact" not in the speculation of the possible meaning of such an incident. However, the dramatist recognizes that through the use of a symbol he can universalize this particular incident. The symbol, therefore, will become the artist's tool to move beyond the action itself and into its possible meaning. Rather than allow the spectator to classify the dropping of the sword as an accident, the dramatist clearly advises him of the imprudence of the courtiers by introducing the scene with the stumbling of the horse and the fall of the rider: a clear signal that what the two gentlemen are about to do is not to be admired.

Awaiting the arrival of his opponent to fight the duel, don Jerónimo notices that his rival is approaching rapidly on a horse that appears to be flying through the air. ${ }^{6}$ The horse belongs, of course, to the element earth and therefore it is unnatural for it to appear flying through the air. To complete the metaphor of the horse and rider, Calderón has the horse stumble and throw the rider, don Pedro, to the ground. In the dramatic works of Calderon the horse represents passion and the rider represents reason. When the horse stumbles and the rider falls to the ground it signifies that passion and instinct have won over reason. Angel Valbuena Briones explains it this way:

La caida del jinete y caballo representa el alma humana en un estado de turbación, cuando el pensamiento del deseo embaraza el recto reciocinio. El j̈̈nete indica en esta exégesis la facultad de la razón que puede dirigir la practica de las virtudes morales, en una concepción tipicamente escolástica. El caballo es la parte del alma que recibe el impacto de los impulsos emotivoso pasionales. Estos en su valor negativo se bifurcan en dos categorias: la soberbía y el apetito carnal. El caballo en su caída o 
estampida señala el peligro de que la pasión vaya a dirigir el alma humana. La razón ha perdido el gobierno. El movimiento del equino expresa la agitación anímica y la velocidad del pensamiento en los casos de carencia de armonia interior. ${ }^{7}$

Skillfully, therefore, the playwright gives the audience the perspective from which to judge the duel - mainly that the two participants are under the influence of passion and that the single combat is the result of this influence. In a sense, the dramatist has improved on history, for he records not only the action but also the point of view from which to judge it.

The third major deviation from the historical accounts occurs at the end of the narrative of the duel. While the chronicle records the matter as it happened, the dramatist is forced to be mindful of his "buen gusto" and record it as it should have happened. Although in the real life, men can and have disobeyed the commands of their king, no such liberty could be taken on the stage of the theater. Sandoval can easily tell us that although the king had commended both gentlemen to be friends and to serve him, he clearly states that they refused and ended their lives as enemies. In Calderón's dramatic version the two accede to the wishes of the king, end their quarrel, and become friends, thereby ending the play on a lower note of a happy ending but nevertheless, a tragedy has been averted. While in history obstinacy and outright rejection of the king's wishes could have been possible, this is not so on the stage of the drama. Taking into account the moral implication of such disobedience, one can understand how impossible it was for Calderón to view the historical ending as an acceptable one. The symbolism inherent in the king would have made such an ending a moral crime. To place personal pride and pundonor above the wishes and express command of a king - especially a benevolent one - would have been a transgression of a moral imperative. Such insubordination in the world of the theatre of the seventeenth century could never go unpunished. Calderón sacrifices history because the dramatic theories of this days demanded that above all other things, the actions that take place on the stage must adhere to a moral principle.

Besides the changes in the narrative of the duel, Calderón also introduces other historical incidents in the play that are outside of the historical time of the main action. In one obvious anachronism, the duel is related to the rebellion of the comuneros and in another he places the reign of Pope Paul III in the second decade of the sixteenth century.

Although it barely qualifies as an anachronism, the rebellion of the comuneros is important because this detail is not present in the historical source of the play. Toward the middle of the third act, immediately after the Emperor admits the petition for a public duel, Charles receives the news that Valladolid is in revolt. He makes haste and arrives in Castile only to be told by the Count of Benavente that he has already quelled the rebellion and that Castile is now at peace.

Historically, in 1520 the cities and towns of Castile initiated an armed protest movement against the equivocal policies followed by Charles $\mathrm{V}$ during his first few years in Spain. The comuneros, as they were called, resented not without cause, the tyrannical rule of the foreigners that Charles had chosen as governors of Spain. The rebellion was quelled 
in 1521 when the forces of the comuneros were defeated by the royalists at the battle of Villalar. Instrumental in the pacification of the rebels was the Count of Benavente. ${ }^{8}$

This historical event, although slightly out of sequence with other events referred to in this play, served Calderón's purpose well, for it must have been a famous example on the question of social order. Although the historical rebellion might have been justifiable, such behavior could not be tolerated on stage. To rebel against the authority of the king was considered one of the worst possible crimes. To Calderón the rebellion signified a state of disorder brought about by man's obedience to passions. In a symbolic plane, therefore, the rebellion is related to the duel in that both exist in a state of disorder. The duel represents disorder on a personal level, while the rebellion of the comuneros represents disorder on a social level. One, like the other is unacceptable and should not be tolerated. Both introduce discord where harmony should rule. Although in real life discord can and at times often wins over order, in the world of the comedia the dramatist always sought to impose order on disorder. The duel is eventually outlawed by the King and the social insurrection is quelled by the Count of Benavente.

Calderón's liberty to adapt historical incidents to the theme of his play is further exemplified by an emendation that he made to one the manuscripts now extant at the National Library of Madrid. ${ }^{9}$ In this manuscript the playwright crossed out the verses that referred to the rebellion of the comuneros and replaced them with a specific reference to a feud between the Manzano and the Monroy families of Salamanca which is, in turn, compared to the violence that occurred between the Guelphs and Ghibellines of medieval Italy.

The feud between the families of the Manzanos and the Monroys had, since its occurrence in the fifteenth century, achieved legendary proportions, symbolizing the hate and vengeance which decimated the two noble families of Salamanca. The historian, Alonso Maldonado, tells us how the feud began. ${ }^{10}$ When Enrique Enríquez died at the beginning of the second half of the fifteenth century, he was survived by his young wife, doña María de Monroy (also known as doña María la Brava), a daughter and two sons - one eighteen years of age and the other nineteen. These two brothers had become friends with two other young men of the Manzano family. One day, while playing ball, they became involved in a dispute with their friends, the Manzanos. The two Monroys were killed in the fight that followed, and the criminals fled to Portugal. Upon seeing the corpses of her two sons, the mother, repressing all tears of grief, departed from Salamanca and with the help of twenty relatives and servants set out in search of her sons' assassins. She surprised them in a house in a small town of Portugal, and before help could arrive, doña María emerged from the house holding in her left hand the heads of her sons' assassins. She returned to Salamanca and deposited the heads of the Manzanos on the tombs of her sons. This dispute gave rise to a bloody and merciless feud between the Manzanos and the Monroys that lasted for many years.

The anachronism in this case is quite obvious: An incident far removed in time from the setting of the play is introduced to broaden the theme of the play. The feud between the Manzanos and the Monroys expands a personal quarrel into a broader social disorder. Although this feud historically occurred at a much earlier date than the 
setting of the paly, thematically it parallels the main action of the play. Both this feud and the duel between don Pedro and don Jerónimo stem from an initial imprudence of the individuals involved. While the dramatic duel does not cause any social disorder - thanks mainly to an alert king - Calderón implies, with his allusion to this historical feud of the fifteenth century, that precisely this kind of violence could be the result of personal quarrels.

At the very end of the play, after Charles forbids the continuation of the duel between don Pedro and don Jerónimo, he directs the Constable to write a letter to Pope Paul III humbly asking him to have the Council of Trent prohibit the fighting of duels in his kingdom. Although it is historically true that the Council of Trent forbade the duel to all Christians, it did not do so until its twenty-fifth session celebrated in 1563. Pope Paul III issued a bull for the Council's convocation in 1542, some twenty years later than the probable setting of the play. We are confronted here with an obvious example of the dramatist's artistic liberty to adapt the historical reality to his dramatic time. However, this conscious distortion, like all the others, has a specific purpose: it contributes directly in the exposition of the central idea.

If the prohibition of the personal combat is important to the main theme, then more complete this prohibition is, the more it emphasizes the evil of those factors that lead two men to fight a duel. By prohibiting this single combat, not only in Spain but also in the whole empire, the condemnation becomes universal. With this action we have the union of the representative of civil order (the king) and the spiritual representative (the pope) for the purpose of condemning the duel both on the social and on the spiritual order.

Calderón recognized the dramatic possibilities in the historical source of El postrer duelo de España and making use of his poetic privilege to adapt history to drama, he transforms for us a specific historical event to one with universal implications. Anachronisms, emendations, and outright distortion of historical truth are not arbitrary changes, but obey a logical thematic development that make them essential to the exposition of the main theme. Throughout the play, the pursuit of a false honor looms paramount in the lives of the main characters. Through his ingenious use of anacronisms, additions, and appropriate changes of historical incidents he shows the evil of such course of action. Calderón's free adaptation of history, thus, is entirely justified in terms of the theme of his play. The many changes that he introduces are not capricious or arbitrary, but are purposely and logically developed to better illustrate the theme of the play: the victory of reason over the false concept of honor. One should be mindful that true to the dramatic theories of his time, Calderón was not giving a lesson on history, but presenting a universal truth through the adaptation of historical incidents. 


\section{NOTES}

${ }^{1}$ In the discussion of "Poetry and History," Aristotle states: "The difference, rather, lies in the fact that the historian narrates events that have actually happened, whereas the poet writes about things as they might possibly occur. Poetry, therefore, is more philosophical and more significant than history, for poetry is more concerned with the universal, and history more with the individual." Poetica (Englewood Cliffs: Prentice-Hall, 1968), p. 17. Echoeing Aristotle's words, Francisco Cascales wrote: "Por donde viene a ser la poesía más excelente que la historia; y la causa es, porque aquélla mira a objeto universal, y ésta particular. De aquí se echa de ver que tomando un suceso como naturaleza lo comenzó y acabó, le hallaremos muchas imperfecciones, y ésas es menester emendarlas con el arte, y perfeccionarlas de manera que no le falte circunstancia necesaria para que aquella obra parezca y sea consumada. Pues esta licencia que tiene el poeta para quitar y poner en la obra de naturaleza, se llama ficción poética." Cartas Filológicas (Madrid: Espasa-Calpe, 1952), II. p. 59.

2 Bances Candamo, "Teatro de los teatros," Revista de Archivos, Bibliotecas y Museos, 5(1901), p. 247.

${ }^{3}$ Albert E. Sloman, The Dramatic Craftsmanship of Calderón (Oxford: Dolphin, 1958). A. A. Parker, "History and Poetry: The Coriolanus Theme in Calderón" in Hispanic Studies in Honour of I. Gonzales LLubera, ed. William F. Pierce, (Oxford: Dolphin, 1959), pp. 211-224.

${ }^{4}$ A. A. Parker, The Approach to the Spanish Drama of the Golden Age (London: Diamante, 1957), p. 23.

5 BAE, 81 (Madrid: Atlas, 1955), pp. 15-18.

${ }^{6}$ The image of the horse flying through the air brings to mind the opening scene of La vida es sueño when Rosaura, under the influence of passion, is thrown by the horse that she likens to an hippogriff.

${ }^{7}$ Angel Valbuena Briones, "El simbolismo en el teatro de Calderón: la caída del caballo," Romanische Forschungen, 74(1962), pp. 75-76.

${ }^{8}$ Diccionario de Historia de España. (Madrid: Revista de Occidente, 1952), I, 717-721.

${ }^{9}$ Ms. 15.273. Although the manuscript was copied by an amanuensis, this emendation was made in Calderón's own hand.

${ }^{10}$ Hechos del Maestre de Alcántara de don Alonso de Monroy, in Memorial Histórico Español (Madrid: Real Academia Española, 1853), VI, pp. 17-19. 